\title{
Publisher Correction: Z-ring membrane anchors associate with cell wall synthases to initiate bacterial cell division
}

\author{
Manuel Pazos ${ }^{1}$, Katharina Peters ${ }^{1}$, Mercedes Casanova², Pilar Palacios ${ }^{2}$, Michael VanNieuwenhze (i] ${ }^{3}$, \\ Eefjan Breukink (1D ${ }^{4}$, Miguel Vicente ${ }^{2} \&$ Waldemar Vollmer ${ }^{1}$
}

Correction to: Nature Communications; https://doi.org/10.1038/s41467-018-07559-2; published online 30 November 2018

The original version of this Article contained errors in Figs. 1 and 3. In Fig. 1b, the label 'IP-PBP3' above the second of the three blots incorrectly read 'IP-PBP1B'. In Fig. 3b, the label 'PBP1B' under the first bar of each chart incorrectly read 'PBP1A'. These errors have been corrected in both the PDF and HTML versions of the Article.

Published online: 30 January 2019

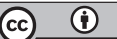

Open Access This article is licensed under a Creative Commons Attribution 4.0 International License, which permits use, sharing, adaptation, distribution and reproduction in any medium or format, as long as you give appropriate credit to the original author(s) and the source, provide a link to the Creative Commons license, and indicate if changes were made. The images or other third party material in this article are included in the article's Creative Commons license, unless indicated otherwise in a credit line to the material. If material is not included in the article's Creative Commons license and your intended use is not permitted by statutory regulation or exceeds the permitted use, you will need to obtain permission directly from the copyright holder. To view a copy of this license, visit http://creativecommons.org/licenses/by/4.0/.

() The Author(s) 2019

\footnotetext{
${ }^{1}$ Centre for Bacterial Cell Biology, Institute for Cell and Molecular Biosciences, Newcastle University, Richardson Road, Newcastle upon Tyne NE2 4AX, UK. ${ }^{2}$ Centro Nacional de Biotecnología-Consejo Superior de Investigaciones Científicas (CNB-CSIC), Darwin 3, 28049 Madrid, Spain. ${ }^{3}$ Molecular and Cellular Biochemistry Department, Biology Department, Indiana University, 212S. Hawthorne Dr, Bloomington, IN 47405, USA. ${ }^{4}$ Membrane Biochemistry and Biophysics, Bijvoet Center for Biomolecular Research, Department of Chemistry, Faculty of Science, Utrecht University, Padualaan 8, 3584 CH Utrecht, The Netherlands. Correspondence and requests for materials should be addressed to W.V. (email: w.vollmer@ncl.ac.uk)
} 